\title{
Laughing Dove Spilopelia senegalensis (Columbiformes: Columbidae): First record for the Madeira Archipelago,
} Portugal

\author{
Ricardo Rocha
}

\begin{abstract}
Universidade de Lisboa, Faculdade de Ciências, Departamento de Biologia Animal, Centro de Biologia Ambiental, Bloco C2, Campo Grande, 1749016. Lisboa, Portugal.

University of Helsinki, Faculty of Biological and Environmental Sciences, Department of Biosciences, P0 Box 65 (Viikinkaari 1), FI-00014. Helsinki, Finland.

E-mail: ricardo.nature@gmail.com
\end{abstract}

\begin{abstract}
An adult Laughing Dove Spilopelia senegalensis (Linnaeus, 1766) was recorded in Deserta Grande Island, Desertas Islands Nature Reserve, Madeira Archipelago, Portugal. This represents the first record of the species for the archipelago and the third confirmed record of S. senegalensis in Portugal.
\end{abstract}

The Laughing Dove Spilopelia senegalensis (Linnaeus, 1766) is a small columbiform native to most of subSaharan Africa, the Middle East and southern Asia east of India and Bangladesh (Baptista et al. 1997). The species has expanded its distribution to the Canary Islands, within the Macaronesian region (de Juana et al. 2000) and has established breeding populations in five of the seven main islands of this Spanish archipelago (Tosco 2010). Throughout its range, $S$. senegalensis is a relatively common species, occupying dry scrub and farmland habitats, and also found close to human settlements. It feeds mainly on small seeds but also eats other plant matter and small insects (Baptista et al. 1997).

This dove species is similar in size and appearance to the Turtle Dove Streptopelia turtur (Linnaeus, 1758), that has been found to breed in the Madeira and Canaries archipelagos (Zino 1991; Tosco 2010). However, S. senegalensis can be easily distinguished from the latter due to the absence of black coloration on the scapulars and inner wing coverts and the different pattern of the neck feathers (Jonsson 1994). This note reports on the first record of $S$. senegalensis in the Madeira archipelago, Portugal.

On 18 October 2009, a solitary S. senegalensis (Figure 1) was observed using a small waterhole in the vicinity of the Madeira Natural Park wardens' house in Deserta Grande Island (32 $31^{\prime} 5.38^{\prime \prime} \mathrm{N}, 16^{\circ} 30^{\prime} 44.30^{\prime \prime} \mathrm{W}, 12 \mathrm{~m}$ asl.), in an area of basaltic rocks surrounded by sparse herbaceous vegetation. This species had not been previously recorded in the archipelago and therefore this record constitutes a new addition to the checklist of the Madeira archipelago (Romano et al. 2010; Equipa Atlas das Aves do Arquipélago da Madeira 2013).

Prior to this record only two other observations of the species had been approved by the Portuguese Rarities Committee of the Portuguese Society for the Study of Birds. Both records occurred in the Portuguese mainland, where one individual was recorded in Cascais in 1996 (Catry et al. 2010) and another in Faro in 2008 (Jara et al. 2010), and were likely escaped captive birds (Catry et al. 2010).
The condition of the beak and feathers of the individual observed in Deserta Grande Island do not suggest that it may have been previously captive. However, despite the fact that Deserta Grande and the two other small islands which constitute the Desertas Islands Nature Reserve are uninhabited, the possibility that the observed bird may have escaped from captivity in Madeira Island, located $25 \mathrm{~km}$ northwest of Deserta Grande, cannot be excluded. The species is an uncommon captive bird in Madeira, and
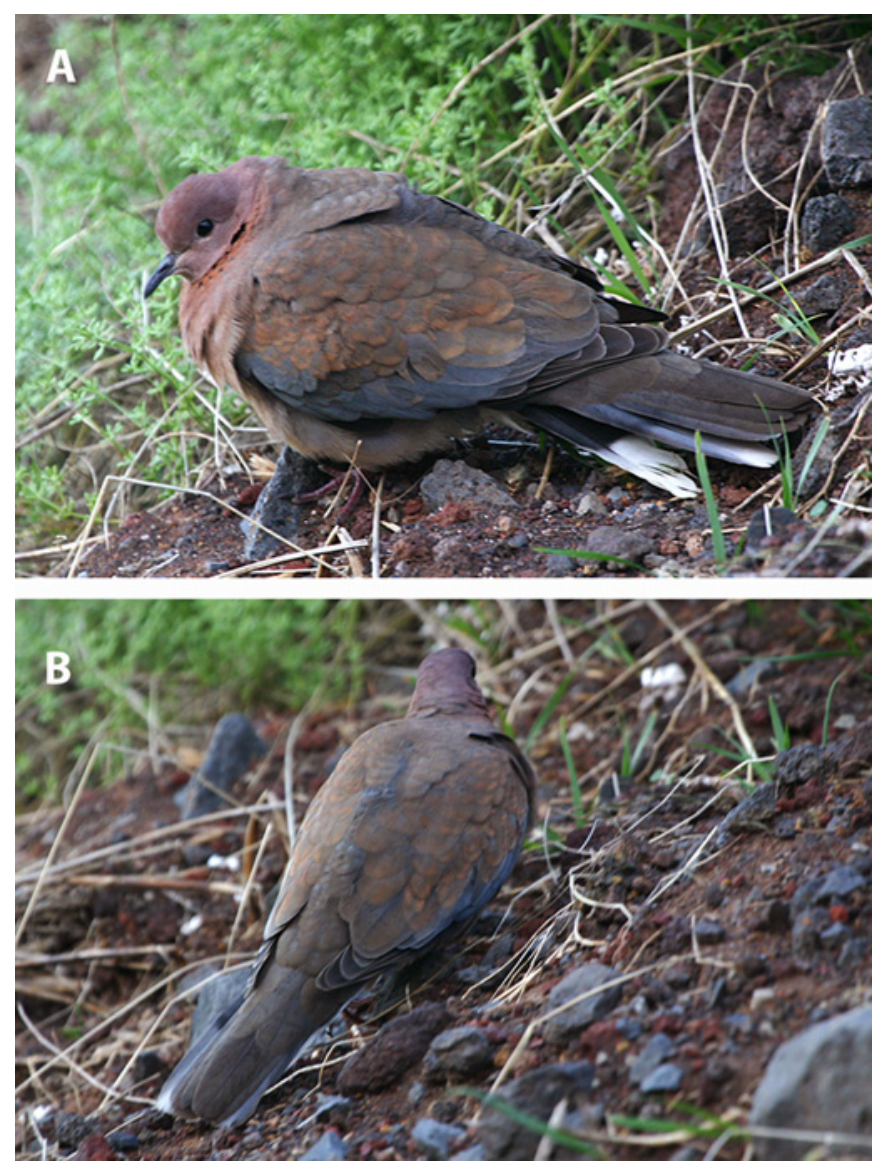

FigurE 1. Lateral (A) and dorsal (B) views of the adult Spilopelia senegalensis observed in Deserta Grande Island, Madeira Archipelago, Portugal. Photos by Ricardo Rocha. 
would have most likely originated from the Canary Islands, located approximately $429 \mathrm{~km}$ southeast of Deserta Grande. The observation reported here constitutes the third confirmed record of $S$. senegalensis in Portugal.

ACKNOWLEDGMENTS: The author wishes to thank the Madeira Natural Park for allowing his work in the Desertas Islands Nature Reserve, Rafael Matias for confirming the identification of the species and commenting on early drafts of this manuscript and Sasha Vasconcelos for revising the English.

\section{Literature Cited}

Baptista, L.F, P.W. Trail and H.M. Horblit. 1997. Order Columbiformes; p. 60-243 In J. del Hoyo, A. Elliott and J. Sargatal (ed.). Handbook of the birds of the world, Volume 4: Sandgrouse to Cuckoos. Barcelona: Lynx Edicions.

Catry, P., H. Costa, G. Elias and R. Matias. 2010. Aves de Portugal: Ornitologia do território continental. Lisboa: Assírio e Alvim. 944 p.

de Juana, E. and Comité de Rarezas de la Sociedad Española de Ornitología. 2000. Report on rare birds in Spain in 1998. Ardeola 47(1): 141-159.

Equipa Atlas das Aves do Arquipélago da Madeira 2013. Atlas das Aves do Arquipélago da Madeira. Electronic Database accessible at http:// www.atlasdasaves.netmadeira.com/. Captured on 08 January 2013.
Jara, J., P. Alfrey, H. Costa, R. Matias, C.C. Moore, J.L. Santos and R. Tipper. 2010. Aves de ocorrência rara ou acidental em Portugal, Relatório do Comité Português de Raridades referente aos anos de 2008. Anuário Ornitológico 7(1): 3-71.

Jonsson, L. 1992. Birds of Europe with North Africa and the Middle East. London: Christoper Helm Publications. 559 p.

Romano, H., C. Correia-Fagundes, F. Zino and M. Biscoito. 2010. Birds of the archipelagos of Madeira and the Selvagens II - New records and checklist update (1995-2010). Boletim do Museu Municipal do Funchal 60(326): 5-44.

Tosco, R.B. 2010. Chordata; p. 367-374 In M. Arechavaleta, S. Rodríguez, N. Zurita and A. García (ed.). Lista de especies silvestres de Canarias. Hongos, plantas y animales terrestres2009. Canarias: Gobierno de Canarias.

Zino, P.A. 1991. Breeding of the Turtle Dove, Streptopelia turtur, in Madeira. Bocagiana 146(1): 1-4.

RECEIVED: September 2012

ACCEPTED: January 2013

PubLISHED ONLINE: May 2013

EDITORIAL RESPONSIBILITY: Dárius P. Tubelis 